\title{
FIELD EMERGENCE AND SEEDLING VIGOUR OF BREAD WHEAT AS INFLUENCED BY METHOD AND LONGEVITY OF STORAGE
}

\author{
S. H. Cheyed
}

Assist. Prof

Field Crop Sciences College of Agriculture Engineering. Sciences, University of Baghdad.

E-mail: saddam.hakeem@ coagri.uobaghdad.edu.iq

\section{ABSTRACT}

A laboratory experiment was carried out in the Seed Technology Laboratory, Department of Field Crop Sciences, College of Agricultural Engineering Sciences, University of Baghdad during the period 2010-2019. That was to evaluate bread wheat seeds stored in spikes in their field emergence and seedling vigour. Seeds, of stored spikes were compared with naked seeds, treated with cruise and untreated. All three treatments of seeds were grown in the laboratory and traits of days to last day of emergence, days to emerge, $\%$ of emergence, and other trails were recorded. Seeds of stored with thein spikes gave better values in days to last day of emergence, days of emergence, percent of emergence, length of plumule, seedling vigour and speed of emergence. The percent of emergence was decreased with increased years of storage, but those stored in their spikes were less affected. It was concluded that storing bread wheat with spikes had better results in field emergence as compared to seeds threshed and stored.

Key words: Triticum aestivum, germination vigour, germination speed, seed storage

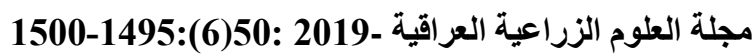

البزوغ الحقلي ونشاط بادرات الحنطة بتأثير طريقة الخزن والخزن طويل الامد

$$
\begin{aligned}
& \text { صدام حكيم جياد } \\
& \text { استاذ مساعد } \\
& \text { قسم المحاصيل الحقلية - كلية علوم الهندسة الزراعية - جامعة بغداد ملياع }
\end{aligned}
$$

نفذت تجربة مختبرية في مختبر تكنولوجيا البذور التابع لقسم المحاصيل الحقلية في كلية علوم الهندة الزراعية -جامعة بغداد خلال السنوات 2010 الى 2019. بهذف تقييم اداء بذور حنطة الخبز المخزونة بسنابلها في تجربة مقارنة مع البذور المفرطة والمعفرة بمبيد الكروزر والبذور المفرطة وغير المعفرة واعتمدت صفات البزوغ الحقلي خلال مدد الخزن التي استمرت

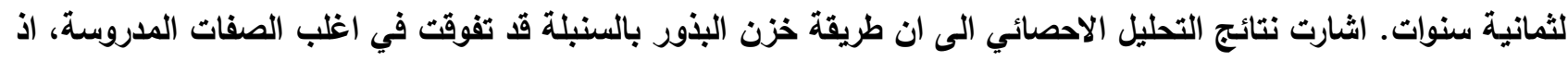
عطت ادنى عدد ايام للوصول الى اخر يوم للبزوغ ومدة البزوغ واعلى متوسط لنسبة البزوغ الحقلي وطول الرويشة وقوة البادرة

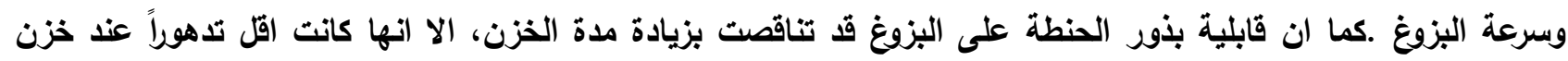

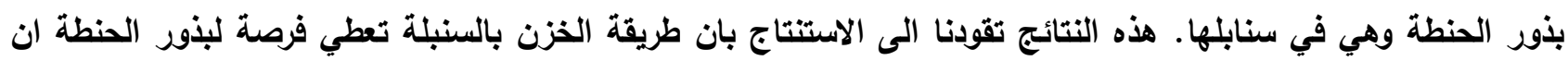
تخفض من تدهورها وتحتفظ بقدرتها على البزوغ لمدة اطول ضمن ظروف الخزن الاعتيادي. الكلمات المفتاحية: .Triticum aestivum ، سرعة البزوغ الحقلي، مدة البزوغ الحقلي، خزن البذور. 


\section{INTRODUCTION}

Bread wheat (Triticum aestivum L.) holds rank 1 of other cereals in the world in area of production and production. However, the annual increase of this crop production is considered insufficient to the population increased in the world. Thus is due to the increase of production in an arithmetic progression, while the world population is increasing in a geometric progression. FAO statistics (7) reported to double of wheat production in the year 2050. One of the factors required for higher production, high yielding cultivars, high quality of seeds to reach better population density which give higher yield (11). Using high quality seeds could increase productivity to $15-20 \%$, and this depends on seed quality to be grown (1). This result has been proved to be true by many investigators, that seeds give vigourous seedlings, will give vigourous plants which lead to higher yield $(5,6)$. Longevity of seeds viability of is affected by cultivar (9), period of storage after maturity (2), since a significant decrease in seed viability as storage period increased (8). When period of storage is long, many physiologic and viability changes will take place, and this will negatively affect seed emergence (26). In such a case, same nonenzymatic oxidation will take place in the seed, damage of cellular membranes, enzymatic damage, and cellular metabolism inhibition (10), proteins relationships and density could also take place (16). All these changes will negatively affect seed quality in emergence and vigour (4, 14, 25). Inconvenient conditions of storage, as usually used by many farmers, that subjected to weather fluctuations could enhance the speed of seed deterioration which be reflected on seed viability and emergence (18). Poor storage could also affect seed tolerance to biotic and abiotic stresses (20). The method of seed storage, treatment, and packaging affect seed quality and longevity of storage. Maize seeds kept on ears gave better emergence than threshed seeds (3). Seeds of wheat stored in their spikes have better adaptation and tolerance to adverse environmental changes (15). Said (24) found that wheat spikes stored for 3, 6, and 9 months gave better emergence. In general, we do not have enough information on stored spikes to keep high viable seeds (17). This research has been assigned to test storing seeds and spikes of some bread wheat cultivars from one to 8 years on field emergence and seedling vigour.

\section{MATERIALS AND METHODS}

AN experiment was undertaken in the Laboratory of Seed Technology, Department of Crop Sciences, College of Agricultural Engineering Sciences, University of Baghdad through 2010-2019. That of bread wheat, unthreshed spikes, stored treated seeds by Cruiser pesticides and untreated seeds, given symbols, S1, S2, and S3, respectively. Storage time was 1 to 8 years. Years of storage were given letters $\mathrm{Y} 1$ to $\mathrm{Y} 8$, respectively. Bread wheat samples were obtained from Ministry of Agric., Office of Agric. Res. of the cultivar Ipa99 in May 2010. Spikes were set into three samples, two of them were threshed, and the third one kept without threshing. Samples were kept into plastic containers of $2 \mathrm{~L}$ and left in room temperature with conditioning. At the end of each storage treatment, 100 seeds were grown in dished of $30 \times 40 \mathrm{~cm}$ containing equal weight of cleaned and sieved field soil. The design used was an RCBD with four replicates using factorial arrangement. These traits were recorded on each experimental unit, first day of emergence (FDE), last day emergence (LDE), and time of emergence (TE), these have been stated as reported by Kader (13). FE; field emergence 10 days from first irrigation, then calculated as percentage:

$\mathrm{FE} \%=($ No. of emerged seedlings $/$ No. of seeds) $\times 100$

Plumule height, above ground (HPL) has been measured on 10 seedlings randomly taken from each experimental unit. Dry weight of seedlings (DWS); 20 seedling were pulled off, cleaned, and dried in the over at $80^{\circ} \mathrm{C}$ for $24 \mathrm{~h}$ then weighed. Speed of emergence (SE), this represented number of seedlings emerged daily related to days of emergence (30). It was calculated by formula: $\mathrm{Gs}=\sum \mathrm{Ni} / \mathrm{Di}$, when $\mathrm{Ni}$ number of emerged seedlings every day, and Di the number of days of emergence. Seeding vigour index (SVI) was estimated according to Murti et al. (21): length of seedling was considered as the lengths of radicle plumule. Data were collected, tabulated, and statistically analyzed according to design used by using 
Genstat. Comparisons were done by counting on LSD values (27).

\section{RESULTS AND DISCUSSION}

The Results of Table 2 shows that cruiser treated and stored seeds (S2) and stored spikes (S1) did not differ in days of first emergence while seeds stored without fungicide (S3) gave longer time for emergence. Results Table 3-5 shows that $\mathrm{S} 1$ treatment was better than other two treatments of storage, since it gave less days to last day of emergence, highest mean emergence, taller plumule, seedling vigour, and speed emergence (8.19 day, 4.28 day, $66.03 \%, 5.31 \mathrm{~cm}, 2.41 \mathrm{~m}$ gm, 16.62 seedling day $^{-1}$ and 737), respectively. Data of same Tables (2-5) also indicate that time for emergence, complete emergence, and time to emergence were decreased as storage time increases, although value of Y1 and Y2 were similar. For year 8 of storage, it gave prover the values than previous years. According to values of interacted variables (method of storage time) were significant in all studied traits except days of emergence and time of emergence. Highly significant interaction was found in Y1 and Y2 in first day of emergence and treated and untreated threshed wheat seeds. The interaction of $\mathrm{S} 2 \times \mathrm{Y} 1$ gave highest value in plumule length, but $\mathrm{S} 2 \times \mathrm{Y} 1$ and $\mathrm{S} 1 \times$ Y1 gave higher value in seedling day weight with similar results of both combinations. The $\mathrm{S} 1 \times \mathrm{Y} 2$ and $\mathrm{S} 2 \times \mathrm{Y} 2$ gave higher men of speed of emergence.

Table 1. Mean squares according to variance analysis for effect of method and period storage on seedling characters

\begin{tabular}{|c|c|c|c|c|c|c|c|c|c|}
\hline S.O.V & df & FDE & LDE & TE & FE & HPL & DWS & SE & SVI \\
\hline Block & 3 & 0.177 & 0.74 & 0.677 & 52.70 & 0.198 & 0.131 & 11.56 & 13923 \\
\hline M & 2 & $5.542 * *$ & $15.04 * *$ & $3.167 *$ & $3772 * *$ & $14.11 * *$ & $1.924 * *$ & $336.56 * * *$ & $1069754 * *$ \\
\hline $\mathbf{P}$ & 9 & $15.62 * *$ & $33.99 * *$ & $4.736 * *$ & $4005 * *$ & 7.97** & $2.183 * *$ & $418.98 * *$ & 927358** \\
\hline $\mathbf{M} \times \mathbf{P}$ & 18 & $0.399^{\mathrm{NS}}$ & $1.21 *$ & $0.678^{\mathrm{NS}}$ & $113 * *$ & $0.184 * *$ & $0.074 * *$ & $5.85^{\mathrm{NS}}$ & $28995 * *$ \\
\hline Error & 90 & 0.249 & 0.52 & 0.663 & 14 & 0.040 & 0.018 & 9.48 & 1588 \\
\hline
\end{tabular}

M: Storage Method. P: Storage Period; * Significant at $\mathbf{p}<0.05$, ** Significant at $\mathbf{p}<0.01$, NS: non significant

Table 2. Effect of method: un-threshed spikes (S1), stored treated seeds by Cruiser pesticides

(S2) and untreated seeds (S3), and storage and storage period (Y1 to Y8) on first day of emergence (FDE) and last day of emergence (LDE).

\begin{tabular}{|c|c|c|c|c|c|c|c|c|}
\hline \multicolumn{5}{|c|}{ FDE (day) } & \multicolumn{4}{|c|}{ LDE(day) } \\
\hline \multirow{2}{*}{$\begin{array}{l}\text { Years } \\
(\mathbf{Y})\end{array}$} & \multicolumn{3}{|c|}{ Method storage } & \multirow[t]{2}{*}{ Mean } & \multicolumn{3}{|c|}{ Method storage } & \multirow[t]{2}{*}{ Mean } \\
\hline & S1 & S2 & $\mathbf{S 3}$ & & S1 & S2 & $\mathbf{S 3}$ & \\
\hline Y1 & 2.75 & 2.00 & 3.00 & 2.58 & 6.50 & 6.25 & 7.25 & 6.67 \\
\hline Y2 & 3.25 & 2.50 & 3.25 & 3.00 & 6.50 & 6.25 & 7.25 & 6.67 \\
\hline Y3 & 3.50 & 2.75 & 3.75 & 3.33 & 7.50 & 7.00 & 7.75 & 7.42 \\
\hline Y4 & 3.25 & 3.75 & 4.25 & 3.75 & 7.75 & 8.25 & 9.25 & 8.42 \\
\hline Y5 & 4.00 & 4.00 & 5.00 & 4.33 & 8.25 & 8.50 & 11.00 & 9.25 \\
\hline Y6 & 4.25 & 4.75 & 5.25 & 4.75 & 9.00 & 11.00 & 11.00 & 10.33 \\
\hline Y7 & 5.00 & 5.50 & 6.00 & 5.50 & 9.50 & 10.25 & 11.25 & 10.33 \\
\hline Y8 & 5.25 & 5.50 & 6.25 & 5.67 & 10.50 & 10.50 & 11.25 & 10.75 \\
\hline Mean & 3.91 & 3.84 & 4.59 & & 8.19 & 8.50 & 9.50 & \\
\hline LSD 0.05 & $\mathrm{M}=\mathbf{0 . 2 5}$ & $Y=0.41$ & $\mathbf{M}$ & $=\mathbf{N} . \mathbf{S}^{*}$ & $M=0.36$ & $Y=0.58$ & M & $=1.01$ \\
\hline
\end{tabular}

* N.S: non significant

Table 3. Effect of method: un-threshed spikes (S1), stored treated seeds by Cruiser pesticides

(S2) and untreated seeds (S3), and storage and storage period (Y1 to Y8) on time of emergence (TE) and field emergence (FE).

\begin{tabular}{|c|c|c|c|c|c|c|c|c|}
\hline \multicolumn{5}{|c|}{ TE (day) } & \multicolumn{4}{|c|}{ FE $(\%)$} \\
\hline \multirow{2}{*}{$\begin{array}{c}\text { Years } \\
\text { (Y) }\end{array}$} & \multicolumn{3}{|c|}{ Method storage } & \multirow[t]{2}{*}{ Mean } & \multicolumn{3}{|c|}{ Method storage } & \multirow[t]{2}{*}{ Mean } \\
\hline & S1 & S2 & S3 & & S1 & S2 & S3 & \\
\hline Y1 & 3.75 & 4.25 & 4.25 & 4.08 & 81.50 & 85.25 & 72.50 & 79.75 \\
\hline Y2 & 3.25 & 3.75 & 4.00 & 3.67 & 77.75 & 85.75 & 64.00 & 75.83 \\
\hline Y3 & 4.00 & 4.25 & 4.00 & 4.08 & 78.00 & 80.00 & 60.00 & 72.67 \\
\hline Y4 & 4.50 & 4.50 & 5.00 & 4.67 & 74.00 & 70.00 & 46.00 & 63.33 \\
\hline Y5 & 4.25 & 4.50 & 6.00 & 4.92 & 63.50 & 60.00 & 42.00 & $\mathbf{5 5 . 1 7}$ \\
\hline Y6 & 4.75 & 6.25 & 5.75 & 5.58 & 56.50 & 48.00 & 31.00 & 45.17 \\
\hline Y7 & 4.50 & 4.75 & 5.25 & 4.83 & 52.00 & 37.00 & 27.00 & 38.67 \\
\hline Y8 & 5.25 & 5.00 & 5.00 & 5.08 & 45.00 & 26.00 & 20.50 & 30.50 \\
\hline Mean & 4.28 & 4.66 & 4.91 & & 66.03 & 61.50 & 45.37 & \\
\hline LSD 0.05 & $\mathrm{M}=\mathbf{0 . 4 1}$ & $Y=0.66$ & & $=\mathbf{N S} *$ & $M=1.86$ & $Y=3.04$ & $\mathbf{M}$ & $=5.27$ \\
\hline
\end{tabular}

* N.S: non significant 
Table 4. Effect of method: un-threshed spikes (S1), stored treated seeds by Cruiser pesticides (S2) and untreated seeds (S3), and storage and storage period (Y1 to Y8) on height plumule above ground (HPL) and dry weight of seedling (DWS).

\begin{tabular}{|c|c|c|c|c|c|c|c|c|}
\hline \multicolumn{5}{|c|}{ HPL (cm) } & \multicolumn{4}{|c|}{ DWS (mg) } \\
\hline \multirow{2}{*}{$\begin{array}{c}\text { Years } \\
(\mathbf{Y})\end{array}$} & \multicolumn{3}{|c|}{ Method storage } & \multirow[t]{2}{*}{ Mean } & \multicolumn{3}{|c|}{ Method storage } & \multirow[t]{2}{*}{ Mean } \\
\hline & S1 & S2 & S3 & & S1 & S2 & S3 & \\
\hline Y1 & 6.18 & 6.72 & 5.17 & 6.03 & 2.87 & 2.92 & 2.46 & 2.75 \\
\hline Y2 & 6.10 & 6.45 & 4.95 & 5.83 & 2.73 & 2.77 & 2.20 & 2.57 \\
\hline Y3 & 5.63 & 5.73 & 4.55 & 5.30 & 2.60 & 2.70 & 2.14 & 2.48 \\
\hline Y4 & 5.60 & 5.05 & 4.15 & 4.93 & 2.56 & 2.44 & 2.20 & 2.40 \\
\hline Y5 & 5.22 & 4.93 & 4.00 & 4.72 & 2.33 & 2.18 & 1.91 & 2.14 \\
\hline Y6 & 4.93 & 4.58 & 3.55 & 4.35 & 2.23 & 2.08 & 1.93 & 2.08 \\
\hline Y7 & 4.50 & 4.13 & 3.40 & 4.01 & 2.05 & 1.87 & 1.54 & 1.82 \\
\hline Y8 & 4.35 & 3.95 & 3.08 & 3.79 & 1.96 & 1.30 & 1.11 & 1.45 \\
\hline Mean & 5.31 & 5.19 & 4.11 & & 2.41 & 2.28 & 1.94 & \\
\hline LSD 0.05 & $\mathbf{M}=\mathbf{0 . 0 9}$ & $Y=0.16$ & $\mathbf{M}$ & $=0.28$ & $\mathbf{M}=\mathbf{0 . 0 7}$ & $Y=0.11$ & M & $=0.18$ \\
\hline
\end{tabular}

Table 5. Effect of method: un-threshed spikes (S1), stored treated seeds by Cruiser pesticides (S2) and untreated seeds (S3), and storage and storage period (Y1 to Y8) on speed of emergence (SE) and seedling vigour index (SVI).

\begin{tabular}{|c|c|c|c|c|c|c|c|c|}
\hline \multicolumn{5}{|c|}{ SE (seedling day ${ }^{-1}$ ) } & \multicolumn{4}{|c|}{ SVI } \\
\hline \multirow{2}{*}{$\begin{array}{c}\text { Years } \\
(\mathbf{Y})\end{array}$} & \multicolumn{3}{|c|}{ Method storage } & \multirow[t]{2}{*}{ Mean } & \multicolumn{3}{|c|}{ Method storage } & \multirow[t]{2}{*}{ Mean } \\
\hline & S1 & S2 & S3 & & S1 & S2 & S3 & \\
\hline Y1 & 22.75 & 20.19 & 17.27 & 20.07 & 1053 & 1199 & 746 & 999 \\
\hline Y2 & 25.40 & 23.21 & 16.52 & 21.71 & 970 & 1134 & 643 & 916 \\
\hline Y3 & 20.02 & 18.97 & 16.20 & 18.40 & 927 & 934 & 544 & 802 \\
\hline Y4 & 17.27 & 15.75 & 9.62 & 14.21 & 843 & 728 & 393 & 655 \\
\hline Y5 & 15.12 & 13.50 & 7.09 & 11.91 & 674 & 609 & 349 & 344 \\
\hline Y6 & 12.02 & 7.80 & 5.48 & 8.44 & 548 & 444 & 226 & 406 \\
\hline Y7 & 11.75 & 8.48 & 5.15 & 8.46 & 480 & 314 & 186 & 326 \\
\hline Y8 & 8.60 & 5.30 & 4.17 & 6.02 & 402 & 211 & 131 & 248 \\
\hline Mean & 16.62 & 14.15 & 10.19 & & 737 & 697 & 402 & \\
\hline LSD 0.05 & $M=1.53$ & $Y=2.51$ & $M \times$ & $=4.34$ & $\mathbf{M}=\mathbf{2 0}$ & $Y=32$ & & $=56$ \\
\hline
\end{tabular}

Results in all Tables shows that mean of period will deteriorate seed viability and the emergence and seedling vigour were highest in treatment of stored spikes. That indicated that storing seeds in spikes is better to protect seeds from some adverse environmental changes (15). This has been reversed by another study which they treated wheat seeds with spike husk water extract gave better protection for seeds for more than 10 months (19). This result is similar to that obtained by Said (24) who found that storing wheat with spikes gave highest emergence as compared to threshed. According to storage period, the results showed that the deterioration of seeds was increased as storage time increased, especially after second year. Classical storage affects seeds quality negatively, and many trails will be deteriorate, besides the infestation by insects, fungi, and fat oxidation for no control on storage temperature (12). This has been confirmed by Oskouei et al. (22) when they showed that seeds stored will be exposed to many changes that cause their deterioration. Das and Tiwari (29) reported that storage resulting seedlings. These results also shows that the interaction between storage method and time storage gave different values for studied traits. Seeds stored with spikes and threshed seeds treated fungicide were better than those stored threshed and untreated with fungicide. This trend was clear as we proceed with years of storage from year 2 to year 8 (Tables 2-5). Tamindzic et al. (28) stated that the fungicide cruse could be has stimulant effect in seed viability. Deterioration after one year was clear and revealed, showing that the fungicide could lose some of its efficiency. Reveal that seeds of stored spikes gave better protection to seeds during storage period up to the eighth year of storage. Seeds stored after thrashing have been infested with Tribolium granarium as it has been diagnosed by specialists in Dept. of Protection in the same College. Mohammed et al. (19) stated that storing wheat spikes will give better protection from Kapra weevil, there was $7 \%$ infestation only, while it was about four folds in threshed 
seeds. This result has been confirmed by Said (24) who compared storing spikes and threshed wheat seeds for 3,6 and 9 months and found that storing wheat with spikes gave better seed protection to the end of storage time. It from the results of experiment could be concluded that storing bread wheat in spikes under un conditioned storage will give better seed quality as compared to those stored threshed under same condition, for spikes give protection to the seeds to end of storage, and those treated with fungicide comes next as compared untreated threshed stored seeds. Storing wheat with spike make it suitable for human consumption as compared to these treated with fungicide.

\section{REFERENCES}

1. Adebisi, M.A., 2004. Variation, Stability and Correlation Studies in Seed Quality and Yield Components of Sesame (Sesamum indicum L.). Ph.D. Dissertation, University of Agriculture, Abeokuta, Nigeria. p:1-2

2. Ali, R. M., M. M. Elsahookie, and F. Y. Bakktash. 2005. Response of maize genotypes to planting season and date of harvest II- Seed quality and vigor parameters. The Iraqi J. Agric. Sci. 36(2):93-102

3. Ali, A.G. 2007. Evaluation of Treasury Susceptibility of Seeds and Germs of Varieties of Maize (Zea mays L.) Stored With Moisture Contents and Different Storage Periods. Ph.D. Dissertation, Agric., Coll., Univ. of Baghdad. pp: 121

4. Biabani A, K. M Mollashahi, M. G. Bahlake, A. Haji and A. G. Khani. 2011. Correlation and relationships between seed yield and other characteristics in chickpea (Cicer arietinum L.) cultivars under deterioration. African J. Agric. Res. 6: 13591362

5. Cheyed, S. H. and M. M. Elsahookie. 2011. Predicting percent of plants in the field giving cultivar mean grain yield and up $(+\ddot{X})$ by vigorous seedlings emerged from sand (SE/96h). The Iraqi J. of Agric. Sci. 42(5)1926

6. Elsahookie, M.M. and F.U. Jannu. 2010. Prediction vigorous plant of maize growth in the field by vigorous seedling emerged from sand (SE/96). The Iraqi J. of Agric. Sci. 41(5)58-66
7. FAO. 2012. World Agriculture Towards 2030/2050: the 2012 Revision. Global Perspective Studies Team FAO Agricultural Development Economics Division. pp:147

8. Ghassemi-Golezani, K. and B. Dalil. 2014. Effects of seed vigor and grain on growth yield of maize. Plant of Seed. Plant Breeding and Seed Sci., DOI: 10.1515

9. Goggi, A.S., P. Caragea, L. Pollak, G. McAndrews, and M. DeVries. 2008. Seed quality assurance in maize breeding programs: Tests to explain variations in maize inbreds and populations. Agron. J. 100 (2): 337 - 343 10. Hampton, J. H. and D. M. Tekrony. 1995. Handbook of Vigour Test Methods $3^{\text {ed }}$ ed. International Seed Testing Association (ISTA), Zurich. pp: 117

11. International Seed Testing Association (ISTA) .1987. Handbook of Vigour Testing Methods. International Seed Testing Association, Zurich, Switzerland. Cold test. pp: $28-37$

12 Justice, A. and N. Bass .1978. Principles and Practices of Seed Storage. Agriculture Handbook No. 506 - United States Department of Agriculture - Agriculture Handbook Number 506 - Prepared by - Sci. and Education Administration. pp:275

13. Kader, M. A. 2005. A comparison of seed germination calculation formulae and the associated interpretation of resulting data. J. and Proceeding of the Royal Society of New South Wales., 138: 65-75

14. Kapoor, N., A. Arya, M.A. Siddiqui, A. Amir and H. Kumar. 2010. Seed deterioration in chickpea (Cicer arietinum L.) under accelerated aging. Asian. J. Plant Sci., 9(3):158-162

15. Karaoglu, M.M., M. Aydeniz, H. G. Kotancilar and K. E. Gercelaslan. 2010. Acomparison of the functional characteristics of wheat stored as grain with wheat stored in spike form. Int. J. of Food Sci. and Tech. 45, 38-47

16. Kausar, M., T. Mahmood, S.M.A. Basra and M. Arshad. 2009. Invigoration of low vigor sunflower hybrids by seed priming. Int. J. of Agric. Biol., 11: 521-528

17. Kibar, H. 2015. Determining the functional characteristics of wheat and corn grains depending on storage time and temperature. J. Food Processing and Preservation 
18. Liu, K., J.M. Baskin, C.C. Baskin, H. Bu, M. Liu, W. Liu and G. Du. 2011.Effect of storage conditions on germination of seeds of 489 species from high elevation grasslands of the eastern Tibet plateau and some implications for climate change. American J. of Botany, 98(1):12-19

19. Mohammed, F. K., H.H. Hamza and R. K. Hussain. 2010. The efficacy of wheat spike husks and its extracts in protecting stored wheat seeds from Trogoderma granariumin infestation were determined. J. of Education Basic College, 2:352-358.

20. Mohammed, L.A. 2004. Effect of storage periods on seed germination of some field crops. The Iraqi J. Agric. Sci., 35(5):61-68

21. Murti, G. S. R., G. S. Sirohi and K. K. Upreti. 2004. Glossary of Plant Physiology. Daya Publishing House. Delhi. pp: 207

22. Oskouei, B., E. H. Majidi, A. Hamidi, F. Moradi and A. Moghadam. 2014. Study on seed vigor deterioration in hybrid corn (Zea mays), cv. single cross 704. Bull. Env. Pharmacol. Life Sci., 3(6): 207-210

23. Pereira, B.L., E.E.L. Borges, A.C. Oliveira, H.G. Leite and J.F.C. Goncalves. 2010. Influência do óxido nítrico na germinação de sementes de Plathymenia reticulata Benth com baixo vigor. Scientia Forestalis, 38(88):629-636

24. Said, M.K.H. 2019. Effect of the Wheat Seeds Storage Method and Period on Severity of Infestation by Khapra Beetle and Red Flour Beetle. M.Sc. Thesis, Collage of Graduate Studies- Sudan Univ. of Sci. Tech., pp:105
25. Siadat S.A., A. Moosavi, and $M$. Sharafizadeh. 2012. Effect of seed priming on antioxidant activity and germination characteristics of maize seeds under different aging treatments. Res. J. of Seed Sci., 5(2): 5162

26. Sibande, G.A.K., V.H. Kabambe, M.F.A Maliro and V. Karoshi. 2015. Effect of priming techniques and seed storage period on soybean (Glycine $\max 1$ ) germination. J. of Dynamics in Agricultural Res., 2(5):46-53

27. Steel, R. G., J. H. Torrie and D. A. Dickey .1997. Principles and Procedures of Statistics, a Biometrical Approach, McGraw Hill Book, Singapore, $3^{\text {rd }}$ ed., McGraw Hill Book, Int. Co., New York, US

28. Tamindzic, G.D., Z. T. Nikoli, J. Z. Savic, D. N. Milosevic, G. R. Petrovic, D. D. Ivanovic and M. V. Ignjatov. 2016. Seedling growth of maize (Zea mays 1.) inbred lines affected by seed treatment with pesticides. 2016. J. of Agric. Sci., 61(3): 227-235.

29. Tiwari, R. K. S. and K. Das. 2014. Impact of differential storage conditions on seed germination and viability of some medicinal plants. African J. Agri. Research., 9(20)15781585

30. Yuan-Yuan, S., S. Yonglian, W. M. Tian, L. X. Yi, G. Xiang, H. Rong and M. Jun. 2010. Effects of seed priming on germination and seedling growth of rice under water stress. Acta Agronomica Sinica. 36(11):1931-1940. 